\title{
Spectrophotometric Determination of Ru(IV) Using 5-Hydroxyimino-4-imino-1,3-thiazolidin-2-one as a Novel Analytical Reagent
}

\author{
Oleksandr Tymoshuk, ${ }^{1}$ Lesia Oleksiv, ${ }^{1, \star}$ Liudmyla Khvalbota, ${ }^{2}$ Taras Chaban ${ }^{3}$ \\ and Ihor Patsay ${ }^{1}$ \\ ${ }^{1}$ Department of Chemistry, Ivan Franko National University of Lviv, Kyryla and Mefodiya Str., 6, 79005 Lviv, Ukraine; \\ ${ }^{2}$ Faculty of Chemical and Food Technology, Slovak University of Technology in Bratislava, Radlinského 9, \\ 81237 Bratislava, Slovakia \\ ${ }^{3}$ Faculty of Pharmacy, Danylo Halytsky Lviv National Medical University, Pekarska Str., 69, 79010 Lviv, Ukraine \\ *Corresponding author: E-mail: l_lozynska@ukr.net
}

Received: 07-17-2018

\begin{abstract}
The interaction of $\mathrm{Ru}(\mathrm{IV})$ ions with a novel analytical reagent - 5-hydroxyimino-4-imino-1,3-thiazolidin-2-one, by spectrophotometric method was investigated. The complex is formed at pH 5.0 in acetate buffer medium after heating in the boiling water bath $(\sim 371 \mathrm{~K})$ for $25 \mathrm{~min}$. The complex has maximum absorption at $350 \mathrm{~nm}$ and is stable for $24 \mathrm{~h}$. Beer's law is valid over the concentration range of $0.5-6.1 \mu \mathrm{g} \mathrm{mL}^{-1}$ for $\mathrm{Ru}(\mathrm{IV})$. The molar absorptivity at $\lambda=350 \mathrm{~nm}$ is $6.21 \times$ $10^{3} \mathrm{~L} \mathrm{~mol}^{-1} \mathrm{~cm}^{-1}$. The limit of detection of this method is $0.2 \mu \mathrm{g} \mathrm{mL}^{-1}$. The interfering effect of various cations and anions on the spectrophotometric determination of the $\mathrm{Ru}(\mathrm{IV})$ were investigated. The proposed method was successfully applied to the determination of $\mathrm{Ru}(\mathrm{IV})$ in alloys.
\end{abstract}

Keywords: Spectrophotometry; ruthenium(IV); 5-hydroxyimino-4-imino-1,3-thiazolidin-2-one.

\section{Introduction}

Ruthenium and its compounds are widely used in various fields: as a catalyst in chemical, petroleum, and pharmaceutical industries, in electrical contacts, resistors, as electrode materials for supercapacitors, and it improves the corrosion properties of alloys, etc. ${ }^{1-3}$ There is a need to develop sensitive, simple and inexpensive methods for the quantitative determination of ruthenium in different samples. For the determination of ruthenium, different analytical techniques such as: voltammetry, atomic absorption spectrometry, high performance liquid-chromatography, thin-layer chromatography, inductively coupled plasma atomic emission, inductively coupled plasma mass spectroscopy are used. ${ }^{3}$ But spectrophotometric methods have been widely used thanks to their simplicity, versatility and cheapness. ${ }^{3-12}$

For spectrophotometric determination of ruthenium, $\mathrm{S}$ and $\mathrm{N}$ containing organic compounds are widely used. ${ }^{3-6,8-12}$ Azolidones belong to such compounds. This class of organic compounds was discovered in the middle of the $20^{\text {th }}$ century. ${ }^{13}$ These compounds exhibit different biological activity, in particular hypoglycemic, antimicrobial, fungicidal, antiviral, antiinflammatory, and antitumor. ${ }^{14-16}$

In our previous studies, the physicochemical properties of the new reagents: 5-hydroxyimino-4-imino-1,3thiazolidin-2-one (HITO), 4-[ $N^{\prime}$-(4-imino-2-oxo-thiazolidin-5-ylidene)-hydrazino]-benzenesulfonic acid and 1-(5-benzylthiazol-2-yl)azonaphthalen-2-ol, which belong to the class of azolidones, and the interaction of Pd(II), Rh(III), Pt(IV), Ir(IV), Cu(II), Zn(II), Cd(II), $\mathrm{Ni}(\mathrm{II})$, and $\mathrm{Hg}$ (II) ions with these reagents were investigated $^{17-28}$ and the methods of their determination with good metrological characteristics were proposed. ${ }^{18-25,27,28}$ Therefore in this paper, we investigated the interaction of ruthenium(IV) ions with 5-hydroxyimino-4-imino1,3-thiazolidin-2-one. 


\section{Experimental}

\section{1. Apparatus}

A ULAB 108-UV computerized spectrophotometer equipped with $1.0 \mathrm{~cm}$ quartz cells was used for absorbance measurements. Absorption spectra were obtained in the wavelength range of $240-600 \mathrm{~nm}$ with the step of $2 \mathrm{~nm}$ using distilled water as a blank.

The $\mathrm{pH}$ measurements and adjustments were performed using $\mathrm{pH}$-meter model $\mathrm{pH}-150 \mathrm{M}$ equipped with a combination glass electrode.

Voltammetric measurements were carried out using oscillopolarograph CLA-03 and computerized polarographic setup equipped with linear potential scan in three-electrode cell (indicator electrode - dropping mercury electrode, reference electrode - saturated calomel electrode and auxiliary electrode - platinum).

Spectrometer Bruker Avance (400 MHz) was used for registration ${ }^{1} \mathrm{H}$ NMR spectra of compounds dissolved in DMSO- $\mathrm{d}_{6}$, internal reference of TMS.

\section{2. Reagents}

All chemicals used in the research were analytically pure and all aqueous solutions were prepared using distilled water.

The stock solution of $\mathrm{Ru}(\mathrm{IV})\left(\left[\mathrm{RuCl}_{6}\right]^{2-}\right)$ was prepared by sintering the exact mass of pure metallic ruthenium $(99.99 \%)$ with the oxidizing mixture of $\mathrm{NaOH}$ and $\mathrm{NaNO}_{3}$ (3:1) in a corundum crucible at $900 \mathrm{~K}(45-60$ $\min )$. The obtained fusion was dissolved in $3.0 \mathrm{~mol} \mathrm{~L}^{-1}$ $\mathrm{HCl}$. The form of $\mathrm{Ru}(\mathrm{IV})$ in the obtained stock solution was identified by the comparison of its absorption spectra with the ones described in the literature. ${ }^{29}$ Because of the possible losses during sintering, the obtained solution of $\mathrm{Ru}(\mathrm{IV})$ was additionally standardized using iodometric titration. ${ }^{3,5}$ Working solutions of $\mathrm{Ru}(\mathrm{IV})$ were prepared by suitable dilution of the stock solution with $1.0 \mathrm{~mol} \mathrm{~L}^{-1}$ hydrochloric acid.

The stock solution of 5-hydroxyimino-4-imino1,3-thiazolidin-2-one was prepared by the dissolution of an exact mass of the reagent in ethanol $(96 \% v / v)$. Working solution of HITO was prepared by dilution the stock solution with water. Synthesis of HITO was carried out according to the methodology given in the literature, ${ }^{30}$ the only difference was the use of $10 \% \mathrm{HCl}$ instead of $5 \%$, that increased the practical yield of the reagent: $5.8 \mathrm{~g}(50 \mathrm{mmol}) 4$-iminothiazolidine-2-one in $10 \% \mathrm{HCl}$ was placed in a $100 \mathrm{~mL}$ round-bottomed flask with a mechanical stirrer and was cooled to 273 $\mathrm{K}$. Then the solution of $10.5 \mathrm{~g}$ sodium nitrite in $20 \mathrm{~mL}$ of water was added dropwise by stirring for $3 \mathrm{~h}$ and the resulting mixture was left for $12 \mathrm{~h}$ at room temperature. The precipitate was filtered, washed with water and acetone, and dried at $60{ }^{\circ} \mathrm{C}$. The yield was $70 \%$. The melting point is $477-480 \mathrm{~K}$. After that the HITO was recrystallized from the ethanol. ${ }^{1} \mathrm{H}$ NMR $\left(400 \mathrm{MHz}\right.$, DMSO-d $\left.{ }_{6} ; \delta, \mathrm{ppm}\right): 8.98 \mathrm{~s}(\mathrm{H}$,
$\mathrm{NH}), 9.34 \mathrm{~s}(\mathrm{H}, \mathrm{NH}), 13.10 \mathrm{~s}(\mathrm{H}, \mathrm{OH})$. The purity of HITO was determined chromatographically with a mass spectrometric detection and it was $100 \%$.

The solutions of $\mathrm{CH}_{3} \mathrm{COONa}$ and $\mathrm{NaOH}$ were prepared by dissolving of appropriate amount of $\mathrm{CH}_{3} \mathrm{COONa}$ and $\mathrm{NaOH}$ in water. The solutions of $\mathrm{HCl}$ and $\mathrm{CH}_{3} \mathrm{COOH}$ were obtained by dilution of concentrated $\mathrm{HCl}$ and $\mathrm{CH}_{3} \mathrm{COOH}$ with water. The universal buffer solutions (UBS) were prepared by mixing $\mathrm{H}_{3} \mathrm{PO}_{4}, \mathrm{H}_{3} \mathrm{BO}_{3}$ and $\mathrm{CH}_{3} \mathrm{COOH} .{ }^{31}$

\section{3. Procedure}

\section{Spectral and protolytic characteristics of the HITO}

In a series of $25.0 \mathrm{~mL}$ calibrated flask the volumes of HITO $\left(8.0 \times 10^{-3} \mathrm{~mol} \mathrm{~L}^{-1}\right), \mathrm{NaCl}\left(2.0 \mathrm{~mol} \mathrm{~L}^{-1}\right)$, UBS $\left(1.5 \mathrm{~mol} \mathrm{~L}^{-1}\right)$ and distilled water $(\sim 15 \mathrm{~mL})$ were added. Then $\mathrm{pH}$ was adjusted in the acceptable range of 2.0-12.0 by $\mathrm{NaOH}\left(4.0 \mathrm{~mol} \mathrm{~L}^{-1}\right)$ and distilled water was added up to the mark. For $\mathrm{pH} 1.0$ the solution was prepared in a similar way, but without adding the UBS and $\mathrm{pH}$ was adjusted by $\mathrm{HCl}\left(6.0 \mathrm{~mol} \mathrm{~L}^{-1}\right)$. Then the absorption spectra were measured against the distilled water.

\section{Recommended procedure for determination of Ru(IV) by using HITO}

An aliquot of the solution that contained 12.5-152.5 $\mu \mathrm{g}$ of $\mathrm{Ru}(\mathrm{IV})$ was transferred into a $25.0 \mathrm{~mL}$ volumetric flask. To this solution $0.125 \mathrm{~mL}$ of $8.0 \times 10^{-3} \mathrm{~mol} \mathrm{~L}^{-1} \mathrm{HITO}$, $1.25 \mathrm{~mL}$ of $2.0 \mathrm{~mol} \mathrm{~L}^{-1} \mathrm{NaCl}, 2.0 \mathrm{~mL}$ of $4.0 \mathrm{~mol} \mathrm{~L}^{-1}$ $\mathrm{CH}_{3} \mathrm{COONa}$, and distilled water $(\sim 15 \mathrm{~mL})$ were added. Then the $\mathrm{pH}$ ( $\mathrm{pH}$ 5.0) was adjusted by means of $\mathrm{CH}_{3} \mathrm{COOH}$ or $\mathrm{CH}_{3} \mathrm{COONa}$ solutions and distilled water was added to complete the volume. After that the solutions were heated in the boiling water bath $(\sim 371 \mathrm{~K})$ for $25 \mathrm{~min}$ and cooled to room temperature ( 293-295 K). The absorbance was measured at $350 \mathrm{~nm}$ against a reagent blank, prepared in the same way but without the addition of $\mathrm{Ru}(\mathrm{IV})$.

\section{Determination of ruthenium in the alloys}

The $\mathrm{Ce}_{45} \mathrm{Ru}_{25} \mathrm{Ga}_{20}$ and $\mathrm{TbRuGa}_{5}$ alloys were prepared by art melting of pure components (not less than 99.9\%) under an argon atmosphere. Then the alloys were annealed in evacuated quartz ampoules at $870 \mathrm{~K}$ for $720 \mathrm{~h}{ }^{32}$

$0.05-0.1 \mathrm{~g}$ of the sample of alloy were dissolved in $10 \mathrm{~mL}$ of $\mathrm{HCl}+\mathrm{HNO}_{3}$ (1:1) mix. The obtained solution was evaporated to wet salts and dissolved in $50.0 \mathrm{~mL}$ of $3.0 \mathrm{~mol} \mathrm{~L}^{-1} \mathrm{HCl}$ solution. If the alloy dissolved incompletely sintering of the new sample with oxidative mixture of $\mathrm{NaOH}$ and $\mathrm{NaNO}_{3}$ (1:3) was carried out. The obtained solution was dissolved in $\mathrm{HCl}$ of $3.0 \mathrm{~mol} \mathrm{~L}^{-1}$ and the content of the beaker was quantitatively transferred into a $250.0 \mathrm{~mL}$ volumetric flask and diluted to the mark with distilled water. If necessary, the solution with lower concentration of ruthenium was prepared by dilution of stock solution with $1.0 \mathrm{~mol} \mathrm{~L}^{-1}$ hydrochloric acid. For ruthe- 
nium determination, the aliquots of alloys $(0.5-1.0 \mathrm{~mL})$ were analyzed as described previously in "Recommended procedure for determination of $\mathrm{Ru}(\mathrm{IV})$ by using HITO". The content of ruthenium was calculated using the method of a normal calibration curve. Voltammetric determination of ruthenium(IV) ions using pyrocatechol violet at $\mathrm{pH} 4.0$ (polarizing range of -0.5 to $-1.5 \mathrm{~V}$ and the potential sweep rate of $0.5 \mathrm{~V} \mathrm{~s}^{-1}$ ) was used as the reference method. ${ }^{33}$

\section{Results and Discussion}

\section{1. Spectral and Protolytic Characteristics of HITO in Water Medium}

The new analytical reagent, 5-hydroxyimino-4-imino-1,3-thiazolidin-2-one (Fig. 1), is a sand color powder, which is poorly soluble in water $\left(0.05 \mathrm{~g} \mathrm{~L}^{-1}\right)$, but soluble in ethanol, methanol, $n$-propanol, isoamyl alcohol, ethylene glycol, glycerol, dimethylformamide and dimethylsulfoxide.

Previous research of the spectral characteristics of HITO $^{18-22}$ has shown that its absorbance spectra depend on $\mathrm{pH}$ (Fig. 2). At $\mathrm{pH} 1.0-6.0$ HITO has a maximum at the wavelength of $264 \mathrm{~nm}, \mathrm{pH} 7.0-267 \mathrm{~nm}$ and at $\mathrm{pH} 8.0-12.0$ two absorption bands: $\lambda=278 \mathrm{~nm}, \lambda=330 \mathrm{~nm}$. Beer's law is applicable at $256 \mathrm{~nm}(\mathrm{pH} \mathrm{5.0)}$ over a wide concentration range (Fig. 3). The molar absorptivity at $\lambda=256 \mathrm{~nm}$ is $1.60 \times 10^{4} \mathrm{~L} \mathrm{~mol}^{-1} \mathrm{~cm}^{-1}$ and at $\lambda=278 \mathrm{~nm}-1.24 \times$ $10^{4} \mathrm{~L} \mathrm{~mol}^{-1} \mathrm{~cm}^{-1}, \lambda=330 \mathrm{~nm}-1.02 \times 10^{4} \mathrm{~L} \mathrm{~mol}^{-1} \mathrm{~cm}^{-1}$. The acid dissociation constant of HITO was found $\left(\mathrm{p} K_{\mathrm{a}}=\right.$ 7.1). This indicates that HITO is a weak acid.

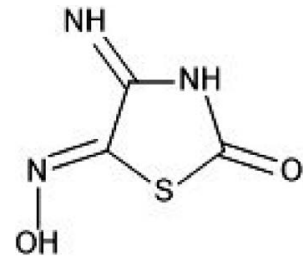

Fig 1. Structural formula of the HITO.

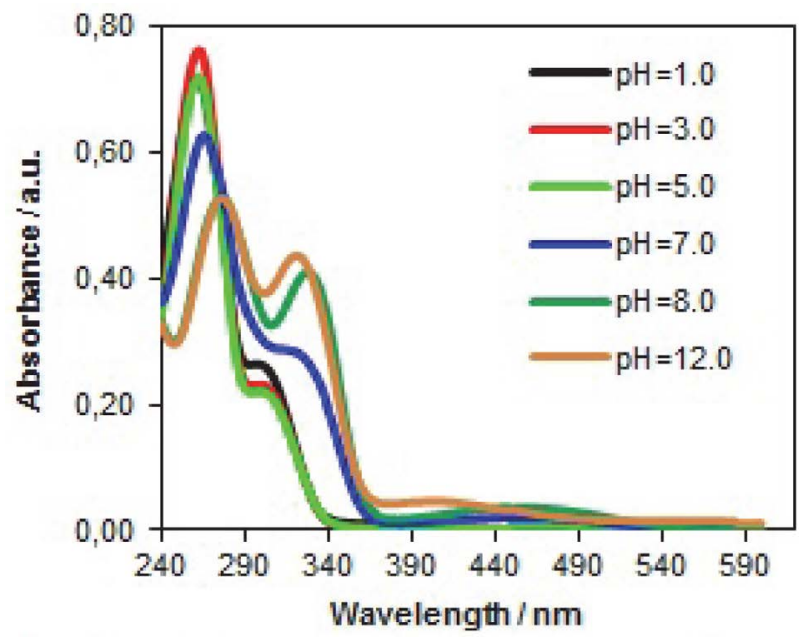

Fig 2. Absorbance spectra of HITO at different $\mathrm{pH}$.

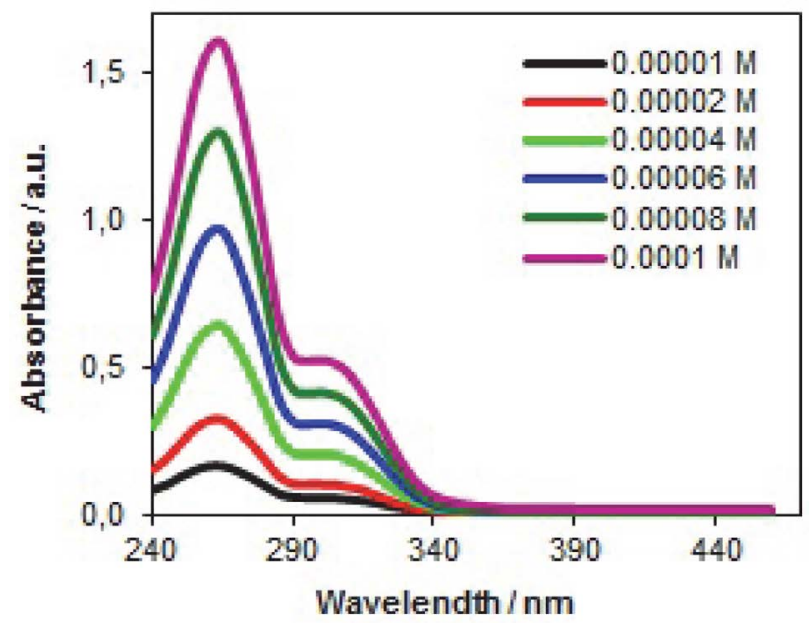

Fig 3. Absorbance spectra of HITO of different molar concentration.

The experimental results show that the absorbance spectra of HITO change over time in the range of $\mathrm{pH}$ 6.0-12.0. The influence of oxygen on the shape of absorption spectra of HITO over time at $\mathrm{pH} 8.0$ and $\mathrm{pH} 9.0$ was checked and it was found that oxygen does not affect the shape of absorption spectra. Therefore, we consider that changes in absorbance spectra of a reagent in the range of $\mathrm{pH}$ 6.0-12.0 are related to the hydrolysis of the imino group, which lasts for $60 \mathrm{~min}$ (Scheme 1). This process is irreversible, since after acidification of solutions to $\mathrm{pH}$ 2.0 spectrum of the reagent did not coincide with the spectrum of HITO in acidic media.<smiles>N=C1NC(=O)S/C1=N/O</smiles>

Scheme 1. Hydrolysis of 5-hydroxyimino-4-imino-1,3-thiazolidin-2-one.

\section{2. Interaction of $\mathrm{Ru}(\mathrm{IV})$ Ions with HITO}

HITO forms with $\mathrm{Ru}(\mathrm{IV})$ ions a complex compound of sandy color in weakly acidic medium, just like with $\mathrm{Pd}(\mathrm{II}), \mathrm{Pt}(\mathrm{IV}), \mathrm{Rh}(\mathrm{III})$, and $\operatorname{Ir}(\mathrm{IV})^{18-22}$. The absorbance spectra of the reagent itself and $\mathrm{Ru}(\mathrm{IV})$-HITO complex are shown in Fig. 4. According to Fig. 4, the maximum difference in absorbance of the HITO and complex compound is at $350 \mathrm{~nm}$. Thus all futher absorbance measurements were carried out at $350 \mathrm{~nm}$ wavelength against reagent blank (where the absorbance of the reagent is negligible). 


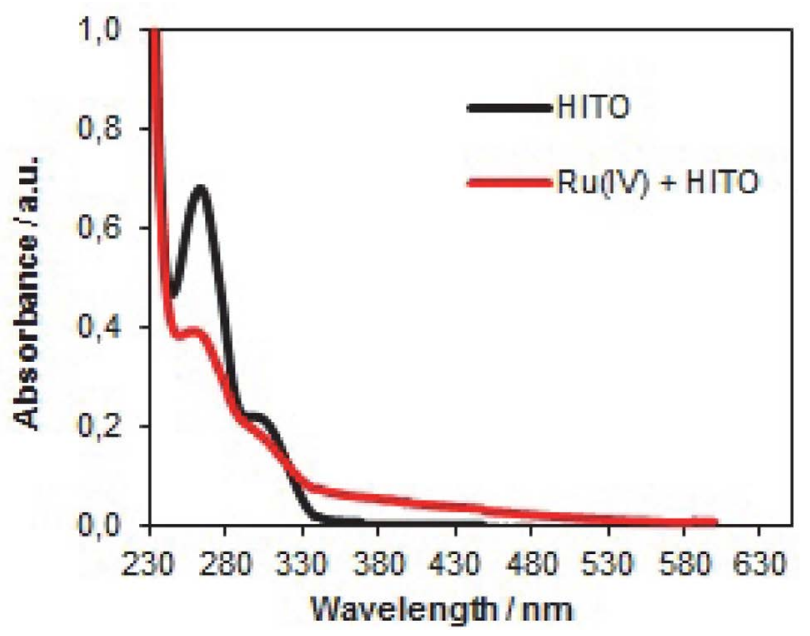

Fig 4. Absorbance spectra of reagent and complex $\mathrm{Ru}(\mathrm{IV})$ with HITO.

The effect of $\mathrm{pH}$ on the absorbance of $\mathrm{Ru}(\mathrm{IV})$-HITO complex compound was investigated over the range 1.07.0 in order to find the optimum conditions (Fig. 5). The optimum $\mathrm{pH}$ range for complex formation lies between $\mathrm{pH}$ 4.5-5.5. So, further investigations were carried out at $\mathrm{pH} 5.0$.

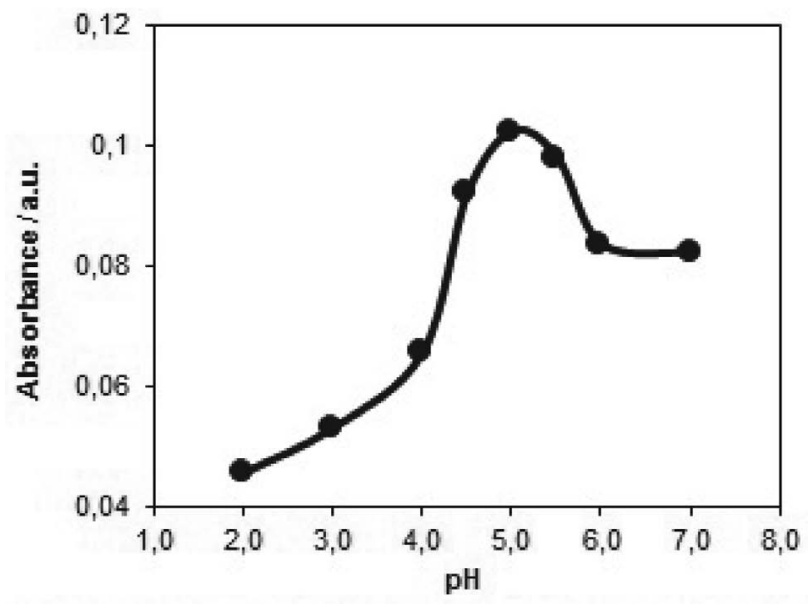

Fig 5. Effect of acidity on the maximum yield of $\mathrm{Ru}(\mathrm{IV})$ with HITO colored complex.

The investigation of the influence of ionic strength on the maximum yield of the complex is necessary for the study of optimal conditions for complexation. Therefore, the influence of the concentration and nature of anions of sodium salts $\left(\mathrm{NaCl}, \mathrm{NaNO}_{3}, \mathrm{NaClO}_{4}, \mathrm{Na}_{2} \mathrm{SO}_{4}, \mathrm{CH}_{3} \mathrm{COONa}\right)$ was investigated. The yield of the complex practically does not depend on the nature of anion. The $\mathrm{SO}_{4}{ }^{2-}$ and $\mathrm{NO}_{3}{ }^{-}$ ions practically do not affect the yield of complex, $\mathrm{ClO}_{4}{ }^{-}-$ in large surpluses slightly decreases the yield of the complex. The yield of the complex insignificantly increases in the presence of $\mathrm{Cl}^{-}$and $\mathrm{CH}_{3} \mathrm{COO}^{-}$ions. Therefore, $\mathrm{NaCl}$ and $\mathrm{CH}_{3} \mathrm{COONa}$ were chosen as a reaction medium.

The interaction of $\mathrm{Ru}(\mathrm{IV})$ ions with HITO at room temperature ( 291-296 K) occurs very slowly. So the possibility of accelerating this process by heating the system in the boiling water bath ( 371 K) was investigated (Fig. 6). The results show the maximum yield of the complex is observed after heating for $25 \mathrm{~min}$ in the boiling water bath $(\sim 371 \mathrm{~K})$. The rapid formation of the Ru(IV)-HITO complex during heating can be related to reduction of the kinetic inertness of the $\left[\mathrm{RuCl}_{6}\right]^{2-}$ complex. The $\mathrm{Ru}(\mathrm{IV})$ HITO complex is stable for $24 \mathrm{~h}$.

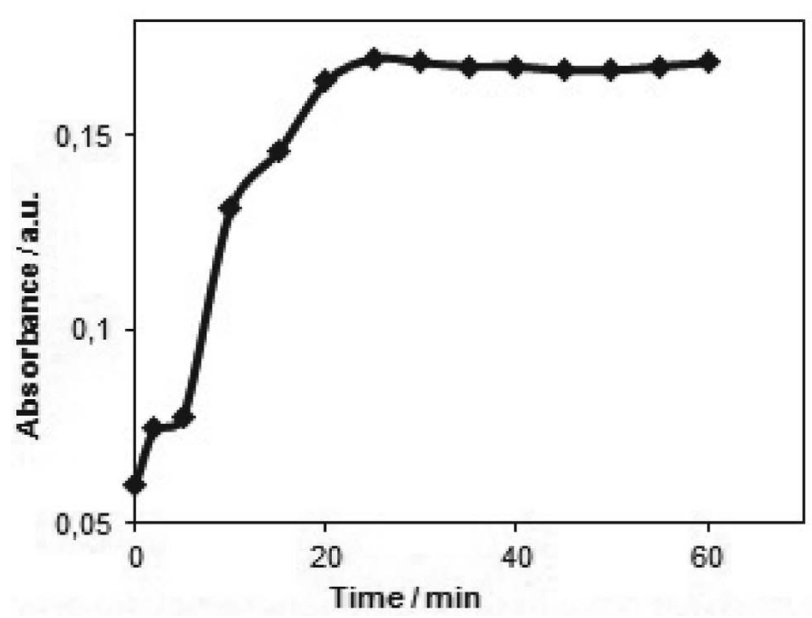

Fig 6. Effect of heating time on the maximum yield of $\mathrm{Ru}(\mathrm{IV})$ with HITO colored complex.

The composition of the complex was determined by the mole-ratio method and the method of continuous variations (Fig. 7). The results of both methods agree and show that the molar ratio of $\mathrm{Ru}(\mathrm{IV})$ to HITO is $1: 1$. It was found that a 1.5-2-fold molar excess of the reagent is suffi-

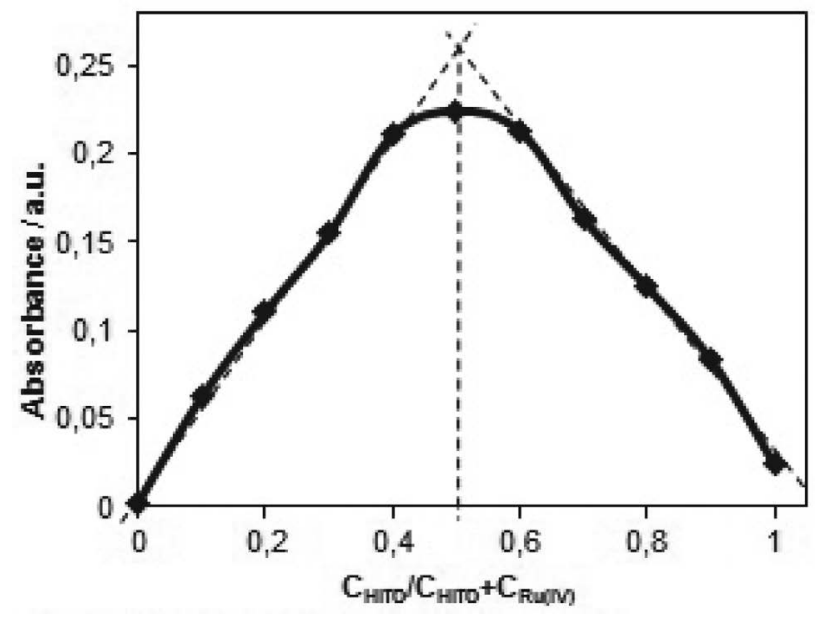

Fig 7. The method of continuous variations. 
<smiles>N=C1NC(=O)S/C1=N/O</smiles>

Scheme 2. The proposed scheme of Ru-HITO complex formation.

cient to obtain maximum absorbances of the $\mathrm{Ru}(\mathrm{IV})$-HITO complex. The formal stability constant is $5.1 \times 10^{6}$.

Based on the experimental results obtained from the study of the interaction of $\mathrm{Ru}(\mathrm{IV})$ ions with HITO and the data given in the literature, ${ }^{34,35}$ it can be assumed that the complex formation most probably takes place as shown in Scheme 2.

Under the optimum conditions a calibration graph for $\mathrm{Ru}(\mathrm{IV})$ was obtained. The Beer's law is obeyed in the range from 0.5 to $6.1 \mu \mathrm{g} \mathrm{mL}^{-1}$ for ruthenium(IV). The molar absorptivity is $6.21 \times 10^{3} \mathrm{~L} \mathrm{~mol}^{-1} \mathrm{~cm}^{-1}$. The metrological characteristics of spectrophotometric determination of ruthenium(IV) with HITO are given in Table 1.

Table 1. The metrological characteristics of spectrophotometric determination of the $\mathrm{Ru}(\mathrm{IV})$ with HITO $\left(C(\mathrm{HITO})=8.0 \times 10^{-4} \mathrm{~mol} \mathrm{~L}^{-1}\right.$; $\mathrm{C}\left(\mathrm{CH}_{3} \mathrm{COOH}+\mathrm{CH}_{3} \mathrm{COONa}\right)=0.32 \mathrm{~mol} \mathrm{~L}^{-1} ; \mathrm{C}(\mathrm{NaCl})=0.1 \mathrm{~mol} \mathrm{~L}^{-1}$; $\mathrm{pH}=5.0 ; \lambda=350 \mathrm{~nm} ; l=1.0 \mathrm{~cm} ; \mathrm{n}=5 ; \mathrm{P}=0.95$ )

\begin{tabular}{lc}
\hline Characteristic & Value \\
\hline Limits of Beer's law, $C_{\mathrm{Ru}(\mathrm{IV})}, \mu \mathrm{g} \mathrm{mL}^{-1}$ & $0.5-6.1$ \\
Calibration equation, $C_{\mathrm{Ru}(\mathrm{IV})}, \mu \mathrm{g} \mathrm{mL}$ & $\Delta \mathrm{A}=0.02+0.06 \times \mathrm{C}$ \\
Limit of detection, $C_{\mathrm{Ru}(\mathrm{IV})}, \mu \mathrm{g} \mathrm{mL} \mathrm{mL}^{-1}$ & 0.2 \\
Limit of quntification, $C_{\mathrm{Ru}(\mathrm{IV})}, \mu \mathrm{g} \mathrm{mL}$ & 0.6 \\
Correlation coefficient, $R$ & 0.9993 \\
\hline
\end{tabular}

\section{3. Effect of Foreign Ions on the Determination of $\mathrm{Ru}(\mathrm{IV})$}

The effect of some potentially interfering ions on the determination of ruthenium(IV) was investigated (Table
2). According to the obtained results most metals, which often accompany ruthenium, such as $\mathrm{Ni}(\mathrm{II}), \mathrm{Co}(\mathrm{II}), \mathrm{Zn}$ (II), $\mathrm{Cd}(\mathrm{II}), \mathrm{Pb}(\mathrm{II}), \mathrm{Mn}(\mathrm{II}), \mathrm{REE}$, and other metals, do not interfere on the determination of $\mathrm{Ru}(\mathrm{IV})$. Instead, the technique is characterized by low selectivity concerning the noble metals or $\mathrm{Cu}(\mathrm{II})$ and $\mathrm{Fe}(\mathrm{III}) . \mathrm{Ag}(\mathrm{I})$ intereferes significantly, even with tolerance limits up to 0.1 , which is due to the influence of chloride ions that are in the solution. The presence of many anions, which were investigated, does not interfere (except EDTA) with the determination of $\mathrm{Ru}(\mathrm{IV})$. The selectivity to some cations can be increased using masking agents. For example, $\mathrm{Cu}(\mathrm{II})$ and $\mathrm{Fe}(\mathrm{III})$ were masked with tartrate ions (the tolerance limits reach 2 for $\mathrm{Cu}(\mathrm{II})$ and 4 for $\mathrm{Fe}(\mathrm{III})$ ), citrate ions (the tolerance limits reach 10 for $\mathrm{Cu}(\mathrm{II})$ and 15 for $\mathrm{Fe}(\mathrm{III})$ ) and phosphate ions (the tolerance limits reach 5 for $\mathrm{Cu}(\mathrm{II})$ and 10 for $\mathrm{Fe}(\mathrm{III})$ ).

\section{4. Application of the Method}

In order to verify the possibility of the proposed method usage, initially the determination of ruthenium in synthetic samples was carried out. These solutions were prepared by adding known amount of the $\mathrm{Ru}(\mathrm{IV})$. The results of analysis $\mathrm{Ru}(\mathrm{IV})$ in synthetic mixture are given in Table 3 .

The method was also applied to the determination of $\mathrm{Ru}(\mathrm{IV})$ in two samples of three-component alloys (Table 4). When ruthenium is added into alloys, mechanical strength increases significantly, while anticorrosion pro-

Table 2. Tolerance limits of foreign ions in $\mathrm{Ru}(\mathrm{IV})$ spectrophotometric determination using HITO $\left(C(\mathrm{HITO})=8.0 \times 10^{-4} \mathrm{~mol} \mathrm{~L}^{-1} ; C(\mathrm{Ru}(\mathrm{IV}))=2.0 \times 10^{-5} \mathrm{~mol} \mathrm{~L}^{-1} ; C(\mathrm{NaCl})=0.1 \mathrm{~mol} \mathrm{~L}^{-1}\right.$; $\left.C\left(\mathrm{CH}_{3} \mathrm{COOH}+\mathrm{CH}_{3} \mathrm{COONa}\right)=0.32 \mathrm{~mol} \mathrm{~L}^{-1} ; \mathrm{pH}=5.0 ; \lambda=350 \mathrm{~nm} ; l=1.0 \mathrm{~cm}\right)$

\begin{tabular}{lccccr}
\hline Ion & $C_{\text {ion }}: C_{\mathbf{R u}(\mathrm{IV})}$ & Ion & $C_{\mathbf{i o n}}: C_{\mathbf{R u}(\mathrm{IV})}$ & Ion & $C_{\mathbf{i o n}}: C_{\mathbf{R u}(\mathrm{IV})}$ \\
\hline $\mathrm{Pd}(\mathrm{II})$ & 0.2 & $\mathrm{Cu}(\mathrm{II})$ & 0.4 & $\mathrm{Al}(\mathrm{III})$ & 30 \\
$\mathrm{Ir}(\mathrm{IV})$ & 0.15 & $\mathrm{~Pb}(\mathrm{II})$ & 100 & $\mathrm{Ba}(\mathrm{II})$ & $>200$ \\
$\mathrm{Rh}(\mathrm{III})$ & 0.15 & $\mathrm{Cd}(\mathrm{II})$ & 100 & $\mathrm{Mg}(\mathrm{II}), \mathrm{Ca}(\mathrm{II})$ & $>200$ \\
$\mathrm{Pt}(\mathrm{IV})$ & 0.14 & $\mathrm{Zn}(\mathrm{II})$ & 100 & $\mathrm{C}_{2} \mathrm{O}_{4}{ }^{2-}$ & 100 \\
$\mathrm{Au}(\mathrm{III})$ & 5 & $\mathrm{Yb}(\mathrm{III})$ & $>200$ & $\mathrm{~F}^{-}$ & $>200$ \\
$\mathrm{Ag}(\mathrm{I})$ & $<0.1$ & $\mathrm{~Tb}(\mathrm{III})$ & $>200$ & $\mathrm{SiO}_{3}{ }^{2-}$ & $>200$ \\
$\mathrm{Hg}(\mathrm{II})$ & 5 & $\mathrm{Ho}(\mathrm{III})$ & $>200$ & $\mathrm{EDTA}^{-}$ & 5 \\
$\mathrm{Co}(\mathrm{II})$ & 50 & $\mathrm{Gd}(\mathrm{III})$ & $>200$ & $\mathrm{Sal}^{-}$ & 45 \\
$\mathrm{Ni}(\mathrm{II})$ & 150 & $\mathrm{Ga}(\mathrm{III})$ & 10 & $\mathrm{Citr}^{3-}$ & $>200$ \\
$\mathrm{Fe}(\mathrm{III})$ & 0.6 & $\mathrm{Ce}(\mathrm{IV})$ & 10 & $\mathrm{Tart}^{2-}$ & 50 \\
$\mathrm{Mn}(\mathrm{II})$ & 100 & $\mathrm{Sn}(\mathrm{II})$ & 3 & $\mathrm{PO}_{4}{ }^{3-}$ & 100 \\
\hline & & & &
\end{tabular}

Tymoshuk et al.: Spectrophotometric Determination of $\mathrm{Ru}(I V) \quad \ldots$ 
Table 3. Determination of $\mathrm{Ru}(\mathrm{IV})$ with HITO in synthetic solutions $(\mathrm{n}=3 ; \mathrm{P}=0.95)$

\begin{tabular}{llccc}
\hline Modeling solution & $C_{\mathrm{Ru}}: C_{\mathrm{ion}}$ & $\begin{array}{c}\text { Added } \\
\mathbf{R u}(\mathbf{I V}), \boldsymbol{\mu g}\end{array}$ & $\begin{array}{c}\text { Found Ru(IV), } \\
\overline{\boldsymbol{x}} \pm \frac{\boldsymbol{s} \times \boldsymbol{t}_{\boldsymbol{\alpha}}}{\sqrt{\boldsymbol{n}}}, \boldsymbol{\mu g}\end{array}$ & $\mathbf{R S D , \%}$ \\
\hline $\mathrm{Ru}-\mathrm{Pd}-\mathrm{Ni}$ & $1: 0.1: 100$ & 38.0 & $39.9 \pm 3.8$ & 4.0 \\
$\mathrm{Ru}-\mathrm{Pt}-\mathrm{Co}$ & $1: 0.1: 30$ & 38.0 & $39.2 \pm 2.9$ & 3.1 \\
$\mathrm{Ru}-\mathrm{Rh}-\mathrm{Zn}$ & $1: 0.1: 50$ & 38.0 & $39.6 \pm 1.9$ & 2.0 \\
\hline
\end{tabular}

Table 4. Determination of ruthenium(IV) in alloys $(n=3 ; P=0.95)$

\begin{tabular}{lccccc}
\hline Intermetallides & \multicolumn{2}{c}{ Spectrophotometry } & \multicolumn{2}{c}{ Voltammetry } \\
& $\omega_{R u}^{c a l c}, \%$ & $\bar{\omega}_{R u}^{p r} \pm \frac{S \times t_{\alpha}}{\sqrt{n}}, \%$ & RSD, \% & $\bar{\omega}_{R u}^{p r} \pm \frac{\boldsymbol{S} \times \boldsymbol{t}_{\alpha}}{\sqrt{\boldsymbol{n}}, \%}$ & RSD, \% \\
\hline $\mathrm{Ce}_{45} \mathrm{Ru}_{25} \mathrm{Ga}_{20}$ & 23.1 & $23.0 \pm 0.9$ & 1.6 & $23.2 \pm 1.2$ & 2.1 \\
$\mathrm{TbRuGa}_{5}$ & 16.6 & $16.4 \pm 0.8$ & 2.0 & $16.7 \pm 0.6$ & 1.4 \\
\hline
\end{tabular}

perties, conductivity, etc. are improved. For these reasons, it is necessary to control the content of ruthenium in multicomponent systems.

The results are in perfect agreement with the ones obtained by voltammetric method. According to the data presented in Table 4 and Table 5, the presented method can be applied to real samples with good reproducibility and accuracy.

Table 5. Comparison of the proposed method with other spectrophotometric methods for the determination of ruthenium(IV)

\begin{tabular}{|c|c|c|c|c|c|}
\hline Reagent & Conditions & $\begin{array}{c}\lambda_{\max } \\
\mathbf{n m}\end{array}$ & $\begin{array}{c}\varepsilon_{\max } \\
\mathrm{L} \mathrm{mol}^{-1} \mathrm{~cm}^{-1}\end{array}$ & $\begin{array}{l}\text { Linear range, } \\
\mu \mathrm{g} \mathrm{mL}^{-1}\end{array}$ & $\begin{array}{l}\text { Interfering } \\
\text { ions }\end{array}$ \\
\hline$N, N^{\star}$-diphenylthiourea ${ }^{4}$ & $\begin{array}{l}\mathrm{HCl}+\mathrm{C}_{2} \mathrm{H}_{5} \mathrm{OH}, \\
6 \mathrm{~mol} \mathrm{~L}-1 \\
\mathrm{CCl}, 5 \min (358 \mathrm{~K})\end{array}$ & $\begin{array}{l}630 ; \\
650\end{array}$ & $\begin{array}{l}-; \\
-\end{array}$ & $\begin{array}{l}6-18 \\
1.5-7.5\end{array}$ & $\begin{array}{c}-; \\
\operatorname{Pt}(\mathrm{IV}), \mathrm{Fe}(\mathrm{II})\end{array}$ \\
\hline Quercetin ${ }^{7}$ & $\begin{array}{l}0.01-0.1 \mathrm{~mol} \mathrm{~L}^{-1} \mathrm{HCl}, \\
\mathrm{CH}_{3} \mathrm{OH}+\mathrm{H}_{2} \mathrm{O}(1: 1)\end{array}$ & 291 & $5.0 \times 10^{3}$ & $0.11-30$ & - \\
\hline 1,10-Phenanthroline ${ }^{4,8}$ & $\begin{array}{l}\text { pH } 6.0 \\
2 \mathrm{~h}(373 \mathrm{~K})\end{array}$ & 448 & $1.9 \times 10^{4}$ & $0.1-1.5$ & Platinoids \\
\hline $\begin{array}{l}\text { 2-[(5-Bromo-2-pyridylazo)]- } \\
5 \text {-diethylaminophenol and } \\
N \text {-hydroxy- } N, N^{c} \text {-diphenyl- } \\
\text { benzamidine }\end{array}$ & $\begin{array}{l}\mathrm{CH}_{2} \mathrm{Cl}_{2} \text {, sodium citrate } \\
\text { dihydrate, sodium acetate }\end{array}$ & 560 & $2.99 \times 10^{4}$ & $0.2-2.8$ & $\begin{array}{l}\mathrm{Pd}(\mathrm{II}), \mathrm{Mn}(\mathrm{II}) \\
\quad \mathrm{Pb}(\mathrm{II})\end{array}$ \\
\hline $\begin{array}{l}\text { 1,4-(2,4-Diphenylthio- } \\
\text { semicarbazide })^{4}\end{array}$ & $\begin{array}{l}5.5-6.5 \mathrm{~mol} \mathrm{~L}^{-1} \mathrm{HCl}, \\
\mathrm{CHCl}_{3}, 10-15 \mathrm{~min}(373 \mathrm{~K})\end{array}$ & 565 & $1.0 \times 10^{4}$ & $0.5-15.0$ & Oxidants \\
\hline$p$-Nitrosodimethylaniline ${ }^{4}$ & $\begin{array}{l}\mathrm{pH} 4.0, \\
50 \min (323 \mathrm{~K})\end{array}$ & 610 & $5.7 \times 10^{4}$ & $0.3-3.0$ & Platinoids \\
\hline $\begin{array}{l}\text { Sulphochlorophenolazo- } \\
\text { rhodanine } \mathrm{e}^{5,10,11}\end{array}$ & $\begin{array}{l}2 \mathrm{~mol} \mathrm{~L}^{-1} \mathrm{HCl}+10 \mathrm{~mol} \mathrm{~L}^{-1} \\
\mathrm{CH}_{3} \mathrm{COOH}, 30 \mathrm{~min}(353 \mathrm{~K})\end{array}$ & 500 & $1.6 \times 10^{4}$ & $0.5-30$ & Pt(IV), Rh(III) \\
\hline $\begin{array}{l}\text { Sulphobenzolazophenol- } \\
\text { azorodanin }{ }^{10}\end{array}$ & $\mathrm{pH} 1.0-3.0$, surfactants & 540 & $4.0 \times 10^{4}$ & - & - \\
\hline Xylenol orange $^{12}$ & $\mathrm{pH} 6.0$ & 575 & $3.23 \times 10^{3}$ & $0.2-2.5$ & $\begin{array}{c}\mathrm{Al}(\mathrm{III}), \mathrm{V}(\mathrm{IV}), \\
\mathrm{Cd}(\mathrm{II}), \mathrm{Cu}(\mathrm{II}), \mathrm{Ni}(\mathrm{II}), \\
\mathrm{Zr}(\mathrm{IV}), \mathrm{Fe}(\mathrm{III}), \mathrm{Hf}(\mathrm{IV}), \\
\mathrm{Zn}(\mathrm{II}), \mathrm{Co}(\mathrm{II}), \mathrm{Pb}(\mathrm{II}), \\
\text { Pd, Pt, Rh }\end{array}$ \\
\hline $\begin{array}{l}\text { 5-hydroxyimino-4-imino- } \\
\text { 1,3-thiazolidin-2-one }\end{array}$ & pH 5.0 & 350 & $6.21 \times 10^{3}$ & $0.5-6.1$ & $\begin{array}{l}\text { Platinoids, } \mathrm{Cu}(\mathrm{II}) \text {, } \\
\text { Fe(III), } \operatorname{Ag}(\mathrm{I})\end{array}$ \\
\hline
\end{tabular}




\section{5. Comparison with other Spectrophotometric Methods}

The proposed method has a better selectivity relative to $\mathrm{Ni}(\mathrm{II}), \mathrm{Co}(\mathrm{II}), \mathrm{Mn}(\mathrm{II}), \mathrm{Cd}(\mathrm{II}), \mathrm{Zn}(\mathrm{II}), \mathrm{Pb}(\mathrm{II}), \mathrm{REE}$, etc. in comparison with other spectrophotometric methods for $\mathrm{Ru}$ determination mentioned in Table 5. There is no need to use highly acidic media and organic solvents.

\section{Conclusions}

This work presents the spectral and protolytic characteristics of the new analytical reagent - HITO and a new spectrophotometric method for the ruthenium(IV) ions determination with this reagent. The developed method is simple, reproducibile, accurate, sufficiently sensitive and selective. It does not require the separation of the matrix and the use of toxic solvents. This method was successfully used for the determination of $\mathrm{Ru}(\mathrm{IV})$ in alloys and synthetic mixtures.

\section{References}

1. Q. Li, S. Zheng, Y. Xu, H. Xue, H. Pang, Chem. Eng. J. 2018, 333, 505-518. DOI:10.1016/j.cej.2017.09.170

2. L. Wang, T. Liu, Chin. J. Catal. 2018, 39, 327-333. DOI:10.1016/S1872-2067(17)62994-2

3. M. Balcerzak, Crit. Rev. Anal. Chem. 2002, 32, 181-226. DOI:10.1080/10408340290765524

4. S. I. Ginzburg, N. A. Yezerskaya, I. V. Prokof'eva, N. V. Fedorenko, V. I. Shlenskaya, N. K. Belsky, Analiticheskaya Khimiya Platinovykh Metallov, Nauka, Moscow, Russia, 1972, p. 613.

5. Ya. A. Zolotov, G. M. Varshal, V. M. Ivanov, Analiticheskaya Khimiya Metallov Platinovoi Gruppy, Editorial URSS, Moscow, Russia, 2003, p. 592.

6. T. D. Avtokratova, Analiticheskaya Khimiya Ruteniya, IAN SSSR, Moscow, Russia, 1972, p. 264.

7. M. Balcerzak, M. Kopacz, A. Kosiorek, E. Swiecicka, S. Kus, Anal. Sci. 2004, 20, 1333-1337. DOI:10.2116/analsci.20.1333

8. A. V. Bashilov, N. M. Kuzmin, V. K. Runov, Zh. Anal. Khim. 1998, 53, $738-743$.

9. P. Ratre, D. Kumar, Int. J. ChemTech Res. 2014, 6, 236-247.

10. R. F. Gur'eva, S. B. Savvin, Usp. Khim. 1998, 67, 236-251. DOI:10.1070/RC1998v067n03ABEH000375

11. R. F. Gur'eva, S. B. Savvin, Zh. Anal. Khim. 1995, 50, 11501157.

12. T. Vrublevs'ka, O. Solovey, O. Volyanyk, Visnyk of the Lviv University. Series Chemistry 2003, 43, 126-129.

13. R. S. Lebedev, Russ. Phys. J. 2002, 45, 822-830. DOI:10.1023/A:1021928817028

14. D. Kaminskyy, B. Zimenkovsky, R. Lesyk, Eur. J. Med. Chem. 2009, 44, 3627-3636. DOI:10.1016/j.ejmech.2009.02.023
15. R. R. Panchuk, V. V. Chumak, M. R. Fil', D. Ya. Havrylyuk, B. S. Zimenkovsky, R. B. Lesyk, R. S. Stoika, Biopolym. Cell 2012, 28, 121-128. DOI:10.7124/bc.00003D

16. T. I. Chaban, O. V. Klenina, B.S. Zimenkovsky, I.G. Chaban, V. V. Ogurtsov, L. S. Shelepeten, Pharma Chem. 2016, 8, 534542.

17. A. Tupys, J. Kalembkiewicz, Y. Ostapiuk, V. Matiichuk, O. Tymoshuk, E. Woźnicka, L. Byczyński, J. Therm. Anal. Calorim. 2017, 127, 2233-2242. DOI:10.1007/s10973-016-5784-0

18. L. Lozynska, O. Tymoshuk, Chem. Chem. Technol. 2013, 7, 391-395. DOI:10.23939/chcht07.04.391

19. L. Lozynska, O. Tymoshuk, In: O.L. Berezko, The Interaction of 5-hydroxyimino-4-imino-1,3-thiazolidin-2-one with Platinum(IV) Ions, $3^{\text {rd }}$ International Conference of Young Scientists CCT-13, Lviv, Ukraine, 2013, 166.

20. L. V. Lozynska, O. S. Tymoshuk, T. I. Chaban, Metody Ob’ekty Khim. Anal. 2014, 9, 50-54. DOI:10.17721/moca.2014.50-54

21. L. V. Lozyns'ka, O. S. Tymoshuk, T. Ya. Vrublevs'ka, Materials Science 2015, 6, 870-876. DOI:10.1007/s11003-015-9795-y

22. L. V. Lozynska, O. S. Tymoshuk, Voprosy Khimii i Khimicheskoi Tekhnologii, 2014, 1, 80-85.

23. L. Lozynska, O. Tymoshuk, T. Chaban, Acta Chim Slov. 2015, 62, 159-167. DOI:10.17344/acsi.2014.866

24. A. Tupys, O. Tymoshuk, P. Rydchuk, Chem. Chem. Technol. 2016, 10, 19-25. DOI:10.23939/chcht10.01.019

25. A. Tupys, J. Kalembkiewicz, Y. Bazel, L. Zapala, M. Dranka, Y. Ostapiuk, O. Tymoshuk, E. Woźnicka, J. Mol. Struct. 2017, 1127, 722-733. DOI:10.1016/j.molstruc.2016.07.119

26. M. Fizer, V. Sidey, A. Tupys, Y. Ostapiuk, O. Tymoshuk, Y. Bazel, J. Mol. Struct. 2017, 1149, 669-682.

DOI:10.1016/j.molstruc.2017.08.037

27. Y. Bazel, A. Tupys, Y. Ostapiuk, O. Tymoshuk, V. Matiychuk, J. Mol. Liq., 2017, 242, 471-477. DOI:10.1016/j.molliq.2017.07.047

28. Y. Bazel, A. Tupys, Y. Ostapiuk, O. Tymoshuk, J. Imricha, J. Šandrejová, RSC Adv., 2018, 8, 15940-15950.

DOI:10.1039/C8RA02039F

29. P. Wehner, J. Hindman, J. Phys. Chem. 1952, 56, 10-15. DOI:10.1021/j150493a003

30. I. D. Komaritsa, Chem. Heterocycl. Compd. 1968, 4, 324-325. DOI: $10.1007 / \mathrm{BF} 00755270$

31. Yu.Yu. Lur'e, Spravochnik po analiticheskoi khimii, Khimiya, Moscow, Russia, 1971, p. 456.

32. O. R. Myakush, A. A. Fedorchuk, A. V. Zelinskii, Neorganicheskiye materialy, 1998, 34, 688-691.

33. T. Vrublevska, O. Tymoshuk Voprosy Khimii i Khimicheskoi Tekhnologii, 2001, 2, 9-11.

34. R. S. Corrêa, M. M. da Silva, A. E. Graminha, C. S. Meira, J. A. F. dos Santos, D.R.M. Moreira, M. B. P. Soares, G. Von Poelhsitz, E. E. Castellano, C. B. Jr, M. R. Cominetti, A. A. Batista, J. Inorg. Biochem. 2016, 156, 153-163. DOI:10.1016/j.jinorgbio.2015.12.024

35. H. Meyer, M. Brenner, S. P. Höfert, T. O. Knedel, P.C. Kunz, A. M. Schmidt, A. Hamacher, M. U. Kassack, C. Janiak, Dalton Trans., 2016, 45, 7605-7615. DOI:10.1039/C5DT04888E 


\section{Povzetek}

Raziskali smo interakcijo $\mathrm{Ru}(\mathrm{IV})$ ionov $\mathrm{z}$ novim analiznim reagentom 5-hydroxyimino-4-imino-1,3-thiazolidin-2-one za uporabo v spektrofotometrični metodi. Kompleks nastane pri pH 5,0 v acetatnem pufru po segrevanju v vreli vodni kopeli ( 371 K) 25 min. Kompleks ima maksimum absorpcije pri $350 \mathrm{~nm}$ in je stabilen $24 \mathrm{~h}$. Beerov zakon velja v koncentracijskem območju 0,5-6,1 $\mu \mathrm{g} \mathrm{mL} \mathrm{mL}^{-1} \mathrm{Ru}(\mathrm{IV})$. Molarna absorptivnost pri $\lambda=350 \mathrm{~nm}$ je $6,21 \times 10^{3} \mathrm{~L} \mathrm{~mol}^{-1} \mathrm{~cm}^{-1}$. Meja zaznave te metode je $0,2 \mu \mathrm{g} \mathrm{mL} \mathrm{mL}^{-1}$. Raziskali smo tudi moteči učinek različnih kationov in anionov na spektrofotometrično določitev $\mathrm{Ru}(\mathrm{IV})$. Predlagano metodo smo uspešno uporabili za določitev $\mathrm{Ru}(\mathrm{IV}) \mathrm{v}$ zlitinah. 